\title{
A MODEL FOR MANAGING LOGISTICS COSTS THROUGHOUT A PRODUCT'S LIFE CYCLE: A CASE STUDY OF A MULTINATIONAL MANUFACTURING COMPANY
}

\author{
Sebastjan ŠKERLIČ ${ }^{*}$, Edgar SOKOLOVSKIJ $2^{2^{*}}$ \\ ${ }^{1}$ Faculty of Maritime Studies and Transport, University of Ljubljana, Portorož, Slovenia \\ ${ }^{2}$ Dept of Automobile Engineering, Vilnius Gediminas Technical University, Lithuania \\ Received 18 January 2019; revised 22 March 2019; accepted 26 March 2019; \\ first published online 28 August 2019
}

\begin{abstract}
The goal of the study is to develop a model that focuses on managing logistics costs at all stages of a product's life cycle. The model includes several different cost components and provides a wider coverage of individual processes, as logistics costs are present in different areas of a company's operations. The applicability of the proposed method was tested in a multinational company that manufactures furniture fittings on a randomly selected product. The test results provide a theoretical and practical confirmation of the necessity to manage the logistics costs for an individual product, since other models are focused exclusively on the cost optimisation of individual logistics processes. The model therefore complements the existing knowledge and represents a practical tool for logistics professionals that enables more efficient logistics costs planning at an early stage in the development of a product, which can result in the long-term reduction in the total costs of logistics and improve the quality of business processes.
\end{abstract}

Keywords: logistics costs, logistics processes, logistics costs management, product's life cycle, manufacturing company, case study.

\section{Introduction}

Logistics costs have certain specific characteristics, as they can be incurred in different business functions within a company, such as sales, purchasing, manufacturing and logistics. How well these costs are managed depends especially on the knowledge of logistics processes and the level of coordination between the business functions involved in the company's supply chain (McCarthy-Byrne, Mentzer 2011; Santa et al. 2011). It starts with the calculation of all the costs that are involved in the life cycle of a product, since various departments within the company are indirectly involved in this process. At this stage of cost planning, we must define the way of distribution, the quantity of stocks, the type of packaging, the purchasing of goods and the internal business processes that support the development and production of the product. Since logistics costs are the result of activities that support the company's logistic process (Kiisler 2008), it is crucial to identify individual logistics costs for the entire life cycle of the product at a very early stage. This is where the core problem arises, because individual functional departments lack sufficient logistical knowledge in certain situations. Other problems may emerge, due to insufficient information (Zanjirani Farahani et al. 2009) and poor coordination between business functions when defining future logistics costs (Škerlič, Muha 2016). All of this can potentially lead to wrong decisions being made, which can significantly affect the level of costs incurred by the company and the quality of supply for the customer.

Over the last thirty years, various cost models have been developed to support the optimisation of logistics activities, which represent the main focus of research and a key practical tool for logistics management. In particular, mathematical cost models have become the basis for optimisation programs that were later developed by companies. However, Rybakov (2018) argues that attempts of practical implementation of optimisation models in logistics systems of companies do not always result in the achievement of specified goals. There is a clear discrepancy between the actual results and specified goals of optimisation programs based on mathematical models.

*Corresponding author. E-mail: sebastjan.skerlic@fpp.uni-lj.si

\#Editor of the TRANSPORT - the manuscript was handled by one of the Associate Editors, who made all decisions related to the manuscript (including the choice of referees and the ultimate decision on the revision and publishing).

Copyright (C 2019 The Author(s). Published by VGTU Press

This is an Open Access article distributed under the terms of the Creative Commons Attribution License (http://creativecommons.org/licenses/by/4.0/), which permits unrestricted use, distribution, and reproduction in any medium, provided the original author and source are credited. 
A detailed scientific literature analysis shows that there are opportunities for improvements in the use of cost models. The extent to which each individual model can be optimised depends on how many different logistics costs are covered by the model. Most models only focus on cost generating activities that are connected to transport, warehousing or stock maintenance costs. Other cost components of the logistics system are not taken into account, which prevents a more comprehensive management of logistics activities that could lead to individual improvements at the company level.

The most recent research is also limited as the proposed models focus exclusively on the cost optimisation of individual logistics processes within distribution, production, or purchasing. The optimisation of logistics costs for each product has been overlooked and has not been studied in detail. By defining logistics costs at an early stage in product development, the future logistics processes that are required for the procurement of input raw materials and for the production and distribution of the product are also identified.

Therefore, the goal of the study is to build on the foundations laid by previous studies with the development of a logistics cost model that can be used as an important decision-making tool at an early stage of logistics cost management for an individual product. The objective of the development of the model is to provide a wider coverage of individual logistics processes, as logistics costs are present in different business areas. The logistics costs management process can involve employees from different business functions (sales, purchasing, logistics, production, etc.) and from different hierarchical levels (management, middle management, operational associates). This ensures vertical and horizontal integration of business functions via a single decision-making tool. It also helps improve the quality of information pertaining to the logistics costs for a particular product and to the logistics processes as support functions for the company's business system. The model enables even those employees who lack the necessary knowledge of logistics, but whose decisions nevertheless influence the level of logistics costs and customer service, to gain some insight into the process of logistics costs management.

The applicability of the proposed model has been tested in a multinational company that manufactures furniture fittings and faces tough competition on a global level. Testing was performed on a product selected at random and encompassed its entire life cycle. A comparison between the current situation and the model testing results identified important suggestions for improvements to logistics costs management in the analysed company. The model complements existing knowledge in the field of logistics costs management and is characterised by a high degree of practicality and usability. It will help build more efficient logistics processes in the early stages of product development, which will reduce the overall costs of logistics in the long run and improve the quality of business processes.

\section{Literature review}

The first studies published about cost optimisation in logistics were conducted due to the need for transport cost rationalisation in the automotive industry in the United States (Blumenfeld et al. 1985, 1987; Burns et al. 1985). The main purpose of model development was to optimise the delivery of goods between different production plants. Logistics cost management has advanced since then, as various studies (Speranza, Ukovich 1994; Bertazzi et al. 1997; Bertazzi, Speranza 1999) began to address the interconnectedness of transport costs and the cost of stocks, as well as the cost of finding the optimal solutions for delivering products from one source to several different destinations.

The studies that followed focused on the optimisation of different logistics costs within individual distribution, internal logistics and purchasing processes. Ghodsypour and O'Brien (2001) have developed a mixed integer nonlinear programming model to solve purchasing and supplier selection problems. The model takes into account the total costs of logistics, including net price, warehousing, transport and ordering costs. Zhao et al. (2004) focused on the internal process by upgrading the traditional economic order quantity model in order to reduce production, stocks and transport costs. By doing so, they essentially optimised the number of orders that are required for production planning at both levels (supplier and buyer). Berman and Wang (2006) focused on the distribution process by building a model that represents a good solution for the future planning and implementation of an efficient distribution network with the lowest total costs of transport and inventories. Chow (2007) also focused on improvements in the area of distribution by developing a model that uses various simulations to show how improvements during transit and more reliable transport can reduce total logistics costs, which also contributes to lower stocks costs. Kutanoglu and Lohiya (2008) present an optimisation-based model to gain insights into the integrated inventory and transportation problem for a single-echelon, multi-facility service parts logistics system with time-based service level constraints. The optimisations objective of the model is to minimise stocks and transport costs while ensuring that service delivery limitations are complied with.

Wang and Cheng (2009) built a logistics scheduling model that successfully proved that if the tasks performed at the level of the supplier, the producer and the buyer have identical processing times, the costs of stocks and transport can be optimised at all levels. The model manages the internal logistics of a company. Madadi et al. (2010) also upgraded the traditional economic order quantity model with the purpose of reducing the costs of maintaining stocks and by taking into account transport costs. A similar study was conducted by Strack and Pochet (2010), who developed a model that combines several stages of the logistic decision-making process, which enable the reduction of warehousing and stocks costs by optimising the quantity of each product in the warehouse. 
Sajadieh et al. (2010) developed a model that highlighted the importance of coordination and cooperation on the axis between seller and buyer in a two-stage supply chain. This kind of relationship results in the most significant reduction in stocks and warehousing costs. Miranda and Garrido (2009) developed a model that deals with the optimisation of stock levels in a two-stage supply chain. The model addresses ordering, warehousing and stocks costs. The aim of the model is to define the optimal ratio between the total operating costs of the system and the optimal stock levels. Lau and Nakandala (2012) focused on internal logistics and developed a mathematical model that supports a series of logistical tasks in the process of managing stock maintenance costs. In this case, taking into account the uncertainty of demand, all the costs incurred by wholesalers in the process of purchasing and maintaining stocks are entered into the model.

Tancrez et al. (2012) developed a strategically structured model that integrates decisions regarding the choice of location for the distribution centres, the allocation of the flows in the network, and the size of individual shipments. The subject of the study are warehousing and stocks costs. Ali and O'Connor (2013) designed a model with the purpose of achieving effective operational planning in the distribution system. The model determines the optimum truck schedule and enables a systematic classification of stocks over a long period of time, which in turn reduces transport and stocks costs. Kim et al. (2015) developed a multi-stage stochastic programming model to optimise the inventory control policy of perishable products and take into account delivery and warehousing costs. Becker et al. (2016) developed a method for analysing the potential of distribution logistics in terms of logistics costs, delivery time and delivery reliability. Perera et al. (2018) studied a single-stage, continuous-time inventory model where unit-sized demands arrive according to a renewal process and show that an $(s, S)$ policy is optimal under minimal assumptions on the ordering/procurement and holding/backorder cost functions. Rybakov (2017) developed a mathematical model for the optimisation of total costs in the logistics systems of the wholesale trading company. To achieve this objective, the structure of the logistics systems was identified and the most substantial cost elements in the logistics subsystems were defined. Petraška et al. $(2017,2018)$ proposed a methodology, which would allow to deliver heavy or oversized freight to the destination, allocating the least possible amount of funds for infrastructure improvements, choosing the most appropriate mode of transport for this type of freight transportation or using the advantages of multimodal (combined) transport. Ji et al. (2018) studied the logistics scheduling problem in the context of a three-stage supply chain where the objective is to minimise the sum of the total weighted inventory cost and transport cost. They analysed the problem using a batching and scheduling model involving both batch supply and batch delivery.

Table 1 outlines the existing scientific literature on the development of logistics cost models. A detailed analysis

Table 1. The existing scientific literature on the development of logistics cost models

\begin{tabular}{|c|c|c|c|}
\hline \multirow{2}{*}{ Authors } & \multirow{2}{*}{ Logistics costs optimisation } & \multicolumn{2}{|c|}{ Orientation of research } \\
\hline & & Process optimisation & Product logistics costs \\
\hline $\begin{array}{l}\text { Proposed model } \\
\text { (by authors in the current } \\
\text { article) }\end{array}$ & $\begin{array}{l}\text { transport distribution, transport purchasing, } \\
\text { warehousing distribution, warehousing purchasing, } \\
\text { stocks, packaging }\end{array}$ & $\begin{array}{l}\text { distribution, } \\
\text { internal processes, } \\
\text { purchasing }\end{array}$ & $\sqrt{ }$ \\
\hline Berman, Wang (2006) & transport, stocks & distribution & - \\
\hline Chow (2007) & transport, warehousing, other costs, stocks & distribution & - \\
\hline Kutanoglu, Lohiya (2008) & transport, stocks & distribution & - \\
\hline Wang, Cheng (2009) & transport, stocks & purchasing & - \\
\hline Miranda, Garrido (2009) & warehousing, stocks, ordering & purchasing & - \\
\hline Madadi et al. (2010) & transport, stocks & purchasing & - \\
\hline Strack, Pochet (2010) & warehousing, stocks & purchasing & - \\
\hline Sajadieh et al. (2010) & warehousing, stocks & purchasing & - \\
\hline Lau, Nakandala (2012) & stocks & internal processes & - \\
\hline Tancrez et al. (2012) & transport, stocks & distribution & - \\
\hline Ali, O’Connor (2013) & transport, stocks & distribution & - \\
\hline Kim et al. (2015) & transport, warehousing, stocks & distribution & - \\
\hline Becker et al. (2016) & transport & distribution & - \\
\hline Perera et al. (2018) & stocks, ordering & purchasing & - \\
\hline Rybakov (2017) & transport, warehousing, stocks & distribution & - \\
\hline Petraška et al. $(2017,2018)$ & transport & distribution & - \\
\hline Ji et al. (2018) & transport, stocks & $\begin{array}{l}\text { distribution, } \\
\text { purchasing }\end{array}$ & - \\
\hline
\end{tabular}


shows that most current models are aimed at optimising the costs of transport, warehousing or maintaining stocks. This means that the other individual cost components of the logistics system, the optimisation of which could bring logistical improvements at the company level, are not considered. The most recent research is also limited in that the proposed models focus exclusively on the cost optimisation of individual logistics processes within distribution, production, or purchasing. The optimisation of logistics costs for each individual product has been overlooked and has not been studied in detail. By defining logistics costs in the product development phase or in the product positioning phase, all future logistics processes that are required in the purchasing of input raw materials, production and distribution of the product are also defined.

The proposed model represents an upgrade of the existing optimisation models, considering the following three aspects: (1) it focuses on treating logistics costs for a product at an early stage in its development; (2) it takes into account several different logistics cost components;
(3) it provides a wider coverage of individual logistics processes, since logistics costs are present in different areas of the business. Additionally, the model fixes the main problems found in the previous study (Škerlič et al. 2016), which focused on the aspect of managing the logistics costs for an individual product, without connecting individual logistics processes.

\section{Model formulation and data entry}

The applicability of the proposed model has been tested in a multinational company that manufactures furniture fittings and supplies its products to more than seventy countries. The group consists of companies from Europe, America, Asia and Australia. Testing was performed on a product selected at random and encompassed its entire life cycle. The data needed to test the model were entered by different departments (sales, purchasing and logistics). Figure 1 illustrates the procedure of data entry into the cost model, which is the basis for the calculation of the
Product costs

\begin{tabular}{|l|l|c|}
\cline { 2 - 3 } \multicolumn{1}{c|}{} & \multicolumn{1}{c|}{ Product } & Data \\
\hline PP & Product Price $[€]$ & 0.13907 \\
\hline NWP & Net Weight of Product [kg] & 0.04648 \\
\hline PLC & Product Life Cycle [years] & 5 \\
\hline PPLC & Pcs in the Product Life Cycle & 1800000 \\
\hline ANP & Annual Need of Products & 360000 \\
\hline ANP & Daily Need of Products & 986 \\
\hline
\end{tabular}

Capital costs in stocks

\begin{tabular}{|c|c|c|}
\hline & Capital in stocks & Data \\
\hline I & Interest & 0.013 \\
\hline DPP & Days of Payment in Purchasing & 60 \\
\hline DPS & Days of Payment in Sales & 45 \\
\hline DSS & Days of Safety Stock & 15 \\
\hline
\end{tabular}

Purchasing warehousing costs

\begin{tabular}{|l|l|c|}
\cline { 2 - 3 } \multicolumn{1}{c|}{} & \multicolumn{1}{c|}{ Purchasing warehousing } & Data \\
\hline TPIM & Total Personal Incomes per Month $[€]$ & 5800 \\
\hline APPH & Average Processed Packaging per Hour & 31 \\
\hline TWEV & Total Warehouse Equipment Values [€] & - \\
\hline TWE & Total Warehouse Equipment [num] & - \\
\hline TWERV & Total Warehouse Equipment Rent Values [€] & 2100 \\
\hline TWER & Total Warehouse Equipment Rent [num] & 3 \\
\hline AP & Amortization Period of Warehouse Equipment & \\
\hline MWH & Monthly Working Hours & 160 \\
\hline
\end{tabular}

Purchasing transport costs

\begin{tabular}{|l|l|c|}
\cline { 2 - 3 } \multicolumn{1}{c|}{} & \multicolumn{1}{c|}{ Delivery from suppliers } & Data \\
\hline TPS $^{1}$ & Transport Price from Supplier & - \\
\hline TPS $^{2}$ & Transport Price from Supplier & 31 \\
\hline TPS $^{3}$ & Transport Price from Supplier & - \\
\hline
\end{tabular}

Packaging costs

\begin{tabular}{|l|l|c|}
\cline { 2 - 3 } \multicolumn{1}{c|}{} & \multicolumn{1}{c|}{ Packaging } & Data \\
\hline WP & Weight of Packaging [kg] & 25 \\
\hline NP & Number of Pieces [in packaging unit] & 8000 \\
\hline PCP & Packaging Cost per Pallet [€] (material) & 18.24 \\
\hline R & Returnable Packaging [YES/NO] & NO \\
\hline RP & Returnable Packaging in Circulation & 0 \\
\hline PS & Packaging Stock & 15 \\
\hline RPV & Returnable Packaging Value [€] (per pallet) & 200 \\
\hline VRP & Value of Returnable Packaging [€] & - \\
\hline
\end{tabular}

Delivery warehousing costs

\begin{tabular}{|l|l|c|}
\cline { 2 - 3 } \multicolumn{1}{c|}{} & \multicolumn{1}{c|}{ Distribution warehousing } & Data \\
\hline TPIM & Total Personal Income per Month [€] & 9280 \\
\hline APPH & Average Processed Packaging per Hour & 47 \\
\hline TWEV & Total Warehouse Equipment Values [€] & - \\
\hline TWE & Total Warehouse Equipment [num] & - \\
\hline TWERV & Total Warehouse Equipment Rent Values $[€]$ & 2650 \\
\hline TWER & Total Warehouse Equipment Rent [num] & 4 \\
\hline AP & Amortization Period of Warehouse Equipment & - \\
\hline MWH & Monthly Working Hours & 160 \\
\hline
\end{tabular}

Delivery transport costs

\begin{tabular}{|l|l|c|}
\cline { 2 - 3 } \multicolumn{1}{l|}{} & \multicolumn{1}{c|}{ Delivery to customers } & Data \\
\hline NSY & Number of Shipments per Year & 12 \\
\hline TT & Transit Time [days] & 4 \\
\hline MFO & Monthly Frequency - One Way & 1 \\
\hline MFR & Monthly frequency - Return & 16360 \\
\hline VC & Vehicle Capacity [kg] & 44 \\
\hline PV & Packaging on Vehicle & 328 \\
\hline OPW & One Way Price [€] & - \\
\hline PRP & Price with Return Packaging [€] & NO \\
\hline DOP & Delivery with Other Products [YES/NO] & \\
\hline
\end{tabular}

Figure 1. Model formulation and data entry 
total logistics costs of the product. The meaning of the individual abbreviations for the formulas is provided, as well as the numerical data entered by the departments within the company. Data entry begins with providing basic information on the product and continues with entering data on individual supporting logistics processes: packaging, distribution warehousing, delivery to customers, capital in stocks, purchasing warehousing and delivery from suppliers. The order in which individual logistics costs are addressed is the reverse of the logistics flow of purchasing. It is adapted to customer needs, which are transferred down the supply chain to the final suppliers.

The general cost (Total Logistics Costs - TLC) model is composed as follows:

$$
T L C=\sum_{i=1}^{n} C_{i},
$$

where: $i$ is the logistics cost component; $n$ is the number of individual logistics cost components; $C_{i}$ is the cost per the selected individual logistics cost component (the model consists of six logistics cost components, where: $C_{1}$ - packaging cost; $C_{2}$ - distribution warehousing costs; $\mathrm{C}_{3}$ - delivery transport costs; $C_{4}$ - capital costs in stocks; $C_{5}$ - purchasing warehousing costs; $C_{6}$ - purchasing transport costs).

The basic model formula consists of individual calculations of Packaging Costs (PC), Distribution Warehousing Costs (DWC), Delivery Transport Costs (DTC), Capital Costs in Stocks (CCS), Purchasing Warehousing Costs (PWC) and Purchasing Transport Costs (PTC), where:

$$
\begin{aligned}
& T L C=P C(R)+D W C+D T C(D O P, R)+ \\
& C C S+P W C+P T C .
\end{aligned}
$$

Individual logistics costs are calculated using the Formula (1), where $P C(R)$ is $C_{1}, D W C$ is $C_{2}, D T C(D O P, R)$ is $C_{3}, C C S$ is $C_{4}, P W C$ is $C_{5}$ and $P T C$ is $C_{6}$. Some logistics costs are presented in terms of functional dependency, namely Packaging Cost (PC) with Returnable packaging (R) and Delivery Transport Costs (DTC) with Delivery with Other Products (DOP) and Returnable packaging (R).

For an easier understanding of the model in practice, abbreviations are used to convey the meaning of each individual variable or formula (Table 2).

\section{Model application}

Model testing was performed, based on the data entered in Figure 1.

\subsection{Packaging costs - PC(R)}

The model offers the option to calculate two different cost aspects of packaging use. If the user of the model marks Returnable packaging (R) with NO, the Non-Returnable Packaging per piece Cost (NRPC) is calculated. If Returnable packaging $(\mathrm{R})$ is marked with YES, the Returnable

\begin{tabular}{|c|c|}
\hline Notation & Abbreviation \\
\hline AER & Average Equipment Rent \\
\hline $\mathrm{AEV}$ & Average Equipment Value \\
\hline $\mathrm{AQO}$ & Average Quantity for Order \\
\hline ANP & Annual Need of Products \\
\hline AP & Amortisation Period \\
\hline APPH & Average Processed Packaging per Hour \\
\hline CCS & Capital Costs in Stocks \\
\hline CCSD & Capital Cost in Stocks per Delivery \\
\hline DOP & Delivery with Other Products \\
\hline $\mathrm{DNP}$ & Daily Need of Products \\
\hline DPP & Days of Payment in Purchasing \\
\hline DPS & Days of Payment in Sales \\
\hline DSS & Days of Safety Stock \\
\hline DTC & Delivery Transport Costs \\
\hline DWC & Distribution Warehousing Costs \\
\hline EWC & External Warehousing Costs per pieces \\
\hline EWP & External Warehousing Price per pallet \\
\hline IA & Inventory Availability \\
\hline $\mathrm{I}$ & Interest \\
\hline MFO & Monthly Frequency - One Way \\
\hline MFR & Monthly Frequency - Return \\
\hline $\mathrm{MWH}$ & Monthly Working Hours \\
\hline NP & Number of Pieces (in packaging unit) \\
\hline NRPC & Non-Returnable Packaging Cost per pieces \\
\hline NS & Number of Shipments \\
\hline NSY & Number of Shipments per Year \\
\hline NWP & Net Weight of Product \\
\hline ORP & Optimal Return Price \\
\hline OTP & Optimal Transport Price \\
\hline OTPP & Optimal Transport Price per Pieces \\
\hline OWP & One Way Price \\
\hline $\mathrm{PC}$ & Packaging Cost \\
\hline PCP & Packaging Cost per Pallet \\
\hline PLC & Product Life Cycle \\
\hline $\mathrm{PP}$ & Product Price \\
\hline PPLC & Pieces in the Product Life Cycle \\
\hline PRP & Price with Return Packaging \\
\hline PS & Packaging Stock \\
\hline PTC & Purchasing Transport Costs \\
\hline PU & Packaging Units (for order) \\
\hline PWC & Purchasing Warehousing Costs \\
\hline $\mathrm{R}$ & Returnable (packaging) \\
\hline $\mathrm{RP}$ & Returnable Packaging (in circulation) \\
\hline RPV & Returnable Packaging Value \\
\hline RPC & Returnable Packaging Cost per pieces \\
\hline RTP & Return Transport Price \\
\hline RTPP & Return Transport Price per Pieces \\
\hline TLC & Total Logistics Costs \\
\hline TPIM & Total Personal Incomes per Month \\
\hline TPP & Transport Price per Pieces \\
\hline TPS & Transport Price from Supplier \\
\hline TT & Transit Time \\
\hline TWE & Total Warehouse Equipment \\
\hline TWER & Total Warehouse Equipment Rent \\
\hline TWERV & Total Warehouse Equipment Rent Values \\
\hline TWEV & Total Warehouse Equipment Values \\
\hline $\mathrm{VC}$ & Vehicle Capacity \\
\hline VDL & Value of Delivery Lot \\
\hline VSS & Value of Safety Stock \\
\hline VRP & Value of Returnable Packaging \\
\hline WEC & Warehouse Equipment Costs \\
\hline WEO & Weight of Each Order \\
\hline WECP & Warehouse Equipment Costs per Pieces \\
\hline WP & Weight of Packaging \\
\hline WSCH & Warehouse Staff Costs per Hour \\
\hline WSCP & Warehouse Staff Costs per Pieces \\
\hline
\end{tabular}
Packaging Cost (RPC) per piece is calculated. As the Pack-
Table 2. Abbreviations for the proposed model 
aging Cost (PC) value depends on the choice of Returnable packaging $(\mathrm{R})$, the calculation is expressed in the form of a $\mathrm{PC}(\mathrm{R})$ function:

$$
P C(R)= \begin{cases}N R P C, & R=N O ; \\ R P C, & R=Y E S .\end{cases}
$$

The calculation of the Non-Returnable Packaging Cost (NRPC) per pieces starts with the definition of the Average Quantity for Order (AQO), where the average Annual Need of Products (ANP) is divided by the Number of Shipments per Year (NSY):

$$
A Q O=\frac{A N P}{N S Y} .
$$

The calculation continues with the definition of the required number of Packaging Units (PU) for the execution of the order, where the Average Quantity for Order (AQO) is divided by the Number of Pieces (NP) in the packaging unit, where ceil $(x)$ is a function that rounds to the smallest integer not less than $x$ :

$$
P U=\operatorname{ceil}\left(\frac{A Q O}{N P}\right) \text {. }
$$

To determine the using Non-Returnable Packaging Cost (NRPC), the resulting number is multiplied by the Packaging Cost per Pallet (PCP) and then divided by the Average Quantity for Order (AQO):

$$
N R P C=\frac{P C P \cdot P U}{A Q O} .
$$

The results of the calculation are: $A Q O=30000$ pcs; $P U=4$ units; NRPC $=€ 0.00243 /$ pcs. The Non-Returnable Packaging Cost (NRPC) per pieces is $€ 0.00243 /$ pcs. If the company decides to use returnable packaging, the calculation option is given below. The basis for the calculation is the sum of monthly Number of Shipments (NS) of goods to the customer, which is then used for the calculation of the number of Returnable Packaging (RP) in circulation. This calculation must include the company's Packaging Stock (PS):

$$
\begin{aligned}
& N S=M F O+M F R \\
& R P=\operatorname{ceil}\left(\frac{A Q O \cdot N S}{N P}+P S\right) .
\end{aligned}
$$

Once the number of Returnable Packaging (RP) in circulation has been determined, the total Value of Returnable Packaging (VRP) is calculated, therefore the value of the individual Returnable Packaging Value (RPV) must be taken into account:

$$
V R P=R P V \cdot R P .
$$

For the final calculation of the Returnable Packaging Cost (RPC) per piece, the total Value of Returnable Packaging (VRP) is divided by the number of all the Pieces in the Product Life Cycle (PPLC):

$$
R P C=\frac{V R P}{P P L C} .
$$

The results of the calculation are: $N S=1 ; R P=14$ pallet; $V R P=€ 2800.00 ; R P C=€ 0.00155 /$ pcs. The Returnable Packaging Cost (RPC) per pieces is $€ 0.00155 /$ pcs. The company uses Non-Returnable Packaging Cost (NRPC) per pieces is $€ 0.00243 /$ pcs.

\subsection{Distribution warehousing costs - DWC}

Distribution Warehousing Costs (DWC) per piece consist of Warehouse Equipment Costs per Piece (WECP), Warehouse Staff Costs per Piece (WSCP) and External Warehousing Costs (EWC) per piece. The calculation begins by defining the Average Equipment Value (AEV) owned by the company and the Average Equipment Rent (AER) value:

$$
\begin{aligned}
& A E V=\frac{T W E V}{T W E} ; \\
& A E R=\frac{T W E R V}{T W E R} .
\end{aligned}
$$

The Average Equipment Value (AEV) is divided by the Amortisation Period (AP) and the number of Monthly Working Hours (MWH). The Average Equipment Rent (AER) value is divided by the number of Monthly Working Hours (MWH). With the sum of both results, the value of the Warehouse Equipment Costs (WEC) per hour is obtained:

$$
W E C=\frac{A E V}{A P \cdot M W H}+\frac{A E R}{M W H} .
$$

When calculating the Warehouse Equipment Costs per Piece (WECP), the following values are taken into account: the number of required Packaging Units (PU) for order, which is calculated using Formula (5), is divided by the Average Processed Packaging per Hour (APPH). The Warehouse Equipment Costs (WEC) per hour are divided by the Average Quantity of products required for the Order (AQO). The two results obtained are multiplied by each other.

$$
W E C P=\frac{P U}{A P P H} \cdot \frac{W E C}{A Q O} .
$$

When calculating the Warehouse Staff Costs per Hour (WSCH), the Total Personal Incomes per Month (TPIM) and the number of Monthly Working Hours (MWH) are taken into account:

$$
W S C H=\frac{T P I M}{M W H} \text {. }
$$

When calculating the Warehouse Staff Costs per Piece (WSCP), the following is taken into account: the number of required Packaging Units (PU) for order, which is calculated using Formula (5), is divided by the Average Processed Packaging per Hour (APPH). The Warehouse Staff Costs per Hour (WSCH) is divided by the Average Quantity of products required for the Order (AQO). The two results obtained are multiplied by each other.

$$
W S C P=\frac{P U}{A P P H} \cdot \frac{W S C H}{A Q O} .
$$


If the company uses a rented warehouse, the External Warehousing Cost (EWC) per piece is calculated. The External Warehousing Price (EWP) per piece is multiplied by the number of required Packaging Units (PU) for order, which is calculated using Formula (5) and divided by the Average Quantity of products required for the Order (AQO).

$$
E W C=\frac{E W P \cdot P U}{A Q O} .
$$

Distribution Warehousing Costs (DWC) per piece are the sum of the results of the Warehouse Equipment Costs per Piece (WECP), the Warehouse Staff Costs per Piece (WSCP) and the External Warehousing Costs (EWC) per piece:

$$
D W C=W E C P+W S C P+E W C .
$$

The company uses exclusively rented warehouse equipment, therefore Average Equipment Rent (AER) value is calculated as $€ 662.50$. The calculation of the Warehouse Equipment Costs (WEC) per hour only takes into account the average value of rented warehouse equipment as well.

The results of the calculation are: $W E C=€ 4.14 / \mathrm{h}$; $W E C P=€ 0.000001 / \mathrm{pcs} ; W S C H=€ 58.00 / \mathrm{h} ; W S C P=$ $€ 0.00016 /$ pcs. Distribution Warehousing Costs (DWC) per piece are $€ 0.00016 / \mathrm{pcs}$.

\subsection{Delivery transport costs - DTC(DOP, R)}

The model offers the option to calculate three different cost aspects of the product's distribution. If the user of the model marks the Delivery with Other Products (DOP) with YES and Returnable packaging (R) with NO, the Optimal Transport Price per Piece (OTPP) is calculated. If, at the next selection, the Delivery with Other Products (DOP) is marked with $\mathrm{NO}$ and returnable packaging (R) is also marked with NO, the Transport Price per Piece (TPP) is calculated. If, at the last selection, the user marks the Delivery with Other Products (DOP) with YES and Returnable packaging (R) with YES, the Returnable Transport Price per Piece (RTPP) is calculated. For this reason, the Delivery Transport Costs (DTC) value is written in the form of the functions of two variables - DOP and R, as:

$$
D T C(D O P, R)=\left\{\begin{array}{lll}
O T P P, & D O P=Y E S, & R=N O ; \\
T T P, & D O P=N O, & R=N O ; \\
R T T P, & D O P=Y E S, & R=Y E S
\end{array}\right.
$$

The company uses Transport Price per Piece (TPP), so only the Optimal Transport Price per Piece (OTPP) and Return Transport Price per Piece (RTPP) calculation model is shown below. Before the final calculation of the OTPP, the Weight of Each Order (WEO) must be entered. The calculation takes into account the Net Weight of the Product (NWP) and the Average Quantity for Order (AQO) of both the product and the Weight of Packaging (WP). The number of Packaging Units (PU) required for the order is calculated using Formula (5).

$$
W E O=N W P \cdot A Q O+W P \cdot P U .
$$

Calculating the Weight of Each Order (WEO) only makes sense, if the company delivers the product in question to the same destination as the other products $D O P=$ $Y E S$, but $R=N O$. In this way, the calculation takes into account the optimal transport vehicle load and it is possible to obtain the Optimal Transport Price (OTP), based on the relative weight of the delivery. The Weight of Each Order (WEO) is multiplied by the One-Way transport Price (OWP) and then divided by Vehicle Capacity (VC). The result obtained is divided by the Average Quantity for Order (AQO).

$$
\begin{aligned}
& \text { OTP }=\frac{O W P \cdot W E O}{V C} ; \\
& O T P P=\frac{O T P}{A Q O} .
\end{aligned}
$$

If the delivery of the product is not combined with the delivery of other products $D O P=N O$ and $R=N O$, the Transport Price per Piece (TPP) is calculated for this shipment only. As the company uses this delivery option, the following formula is used:

$$
T P P=\frac{O W P}{A Q O},
$$

the Transport Price per Piece (TPP) is calculated as $€ 0.01093 /$ pcs.

If the delivery of the product is combined with the delivery of other products $D O P=Y E S$ and the responsibility for receiving returnable packaging is indicated $R=Y E S$, the Returnable Transport Price per Piece (RTPP) is calculated. The calculation of the Return Transport Price (RTP) includes the total of all the prices of one-way transports and all the monthly return transports, which is then divided by the Number of monthly Shipments (NS). NS is calculated using Formula (7).

$$
R T P=\frac{O W P \cdot M F O+P R P \cdot M F R}{N S} .
$$

When calculating the Optimal Return Price (ORP), we must take into account the Weight of Each Order (WEO, Formula (2)) and the Return Transport Price (RTP) obtained, which is then divided by the transport Vehicle Capacity (VC). The resulting number is divided by the Average Quantity for Order (AQO, Formula (4)).

$$
\begin{aligned}
& O R P=\frac{R T P \cdot W E O}{V C} ; \\
& R T P P=\frac{R O T}{A Q O} .
\end{aligned}
$$

\subsection{Capital costs in stocks - CCS}

In order to calculate the Capital Costs in Stocks (CCS) per piece, we must first define the Value of the Delivery Lot (VDL), where the Average Quantity of products for the Order (AQO, Formula (4)) is multiplied by the Price of the Product (PP):

$$
V D L=A Q O \cdot P P .
$$


To calculate the Value of the Safety Stock (VSS), the Daily Need of Products (DNP) is multiplied by the Days of the Safety Stock (DSS) and the Product Price (PP):

$$
V S S=D N P \cdot D S S \cdot P P \text {. }
$$

In order to calculate the Capital Costs in Stocks (CCS) per piece, we must first define the annual IOnventory Availability (IA) in days, which includes the following formula (Kivinen, Lukka 2004):

$$
I A=\frac{365 \text { days }}{\text { NSY }} \text {. }
$$

The Inventory Availability (IA) value is added to the factors that influence how long the capital is tied-up in stocks, such as Days of Payment in Sales (DPS) and the Days of Safety Stock (DSS). The number of Days of Payment in Purchasing (DPP) is deducted. The final result is also affected by the Value of the Delivery Lot (VDL), the Value of the Safety Stock (VSS) and the Interest (I). The result obtained represents the Capital Cost in Stocks per Delivery (CCSD), which is then divided by the Average Quantity of products for Order (AQO, Formula (4)). The final result is the Cost of Capital in Stocks (CCS) per piece.

$$
\begin{aligned}
& C C S D=\frac{I A+D P S+D S S-D P P}{365 \text { days }} \cdot(V D L+V S S) \cdot I ; \\
& C C S=\frac{C C S D}{A Q O} .
\end{aligned}
$$

The results of the calculation are: $V D L=€ 4172.1$; VSS $=€ 2056.84 ; I A=30.41$ days; $C C S D=€ 6.7461 ;$ CCS $=€ 0.00022 / \mathrm{pcs}$.

\subsection{Purchasing warehousing costs - PWC}

The Purchasing Warehousing Costs (PWC) consist of the Warehouse Equipment Costs per Piece (WECP), the Warehouse Staff Costs per Piece (WSCP) and External Warehousing Costs (EWC) per piece and is calculated according to the following formula:

$$
P W C=W E C P+W S C P+E W C \text {. }
$$

The costs refer to the operation of the warehouse at the receipt of goods all calculations are structured in the same way as when calculating distribution warehousing costs per piece (see Subsection 3.2.). We start by defining the Average Equipment Value (AEV) owned by the company using Formula (11) and the Average Equipment Rent (AER) value using Formula (12). Formula (13) is used to calculate the Warehouse Equipment Costs (WEC) per hour and Formula (14) is used to calculate the Warehouse Equipment Costs per Piece (WECP). To calculate the Warehouse Staff Costs per Piece (WSCP), Formula (15) is used first and then Formula (16). If the company uses a rented warehouse, the External Warehousing Costs (EWC) per piece are calculated using Formula (17). Since the company uses rented warehouse equipment, Average Equipment Rent (AER) value is calculated and amounts to $€ 700.00$. The calculation of the Warehouse Equipment Costs (WEC) per hour only takes into account the average value of rented warehouse equipment as well.

The results of the calculation are: $W E C=€ 4.37 / \mathrm{h}$; $W E C P=€ 0.000018 / \mathrm{pcs} ; W S C H=€ 36.25 / \mathrm{h} ; W S C P=$ $€ 0.00015 / \mathrm{pcs} ; P W C=€ 0.00016 / \mathrm{pcs}$.

\subsection{Purchasing transport costs - PTC}

If the company organises the transport of goods from the suppliers to its production plant, the sum of the costs of picking up the goods from the individual suppliers is taken into account. Since the company that was the subject of the study does not organise its own transports, a calculation proposal is given:

$$
P T C=\frac{T P S_{1}+T P S_{n}}{A Q O} .
$$

\subsection{Total logistics costs - TLC}

The Total Logistics Costs (TLC) are calculated according to Formula (2) as the sum of the individual calculations of Packaging Costs (PC (R)0, Distribution Warehousing Costs (DWC), Delivery Transport Costs (DTC(DOP, R)), Capital Costs in Stocks (CCS), Purchasing Warehousing Costs (PWC) and Purchasing Transport Costs (PTC).

The Total Logistics Costs (TCL) are $€ 0.013941 / \mathrm{pcs}$.

\subsection{Sensitivity analysis}

A sensitivity analysis was conducted, which showed a linear dependence of the final results with respect to the change in the value of individual input cost variables. An increase of 5, 10 and $15 \%$ of the transport service price showed a linear increase in delivery transport costs and total logistics costs. Other logistics costs components remained stable. The same effect was seen in the 5,10 and $15 \%$ increase in packaging costs per palette on the total logistics costs. The analysis therefore focused on testing one of the most sensitive parameters in the logistics system of companies - the impact of increasing deliveries to the customers on the total logistics costs. This is also a very important parameter in theoretical studies (Ballou 2003; Stock, Lambert 2000; Shang 2004; Waller, Fawcett 2012; Juntunen et al. 2015) and it highlights two important aspects of logistics costs management:

- an improvement in the quality of logistics services for customers results in higher total logistics costs;

- reducing the costs of one logistic component causes an increase in the costs of another logistic component, which results in higher total logistics costs.

The results of the sensitivity analysis shown in Figure 2 have also been confirmed in practice. The company currently supplies its customers 12 times a year. Any increase in the number of deliveries directly affects all individual logistics cost components.

As the number of shipments increases, distribution transport costs and total logistics costs are also increasing, while capital costs in stocks are decreasing. This fluc- 

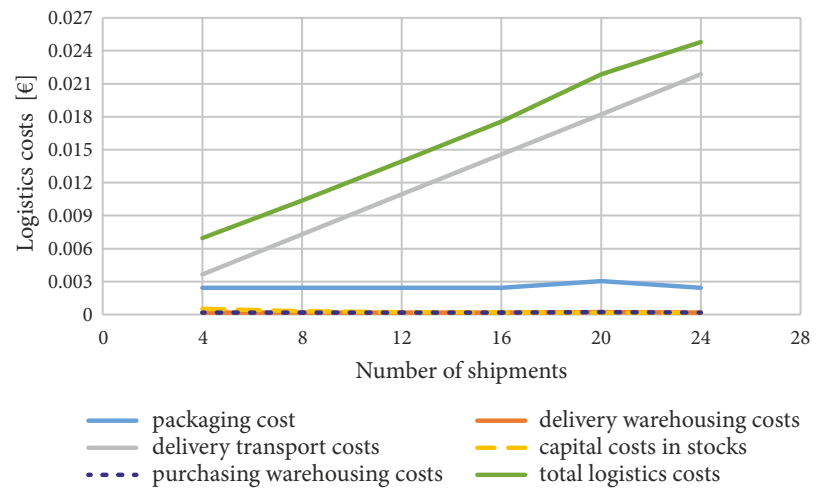

Figure 2. The impact of the number of shipments per year on logistics costs

tuation becomes apparent at the twentieth shipment. The costs of capital in stocks are still on the decrease, while packaging costs, distribution warehousing costs and purchasing warehousing costs, which had remained stable until that moment, show a slight increase. The total logistics costs show a non-linear increase, followed by a slight decrease at the 24 shipment.

\section{Discussion}

A comparison between the current state of logistics cost management and the model testing results are shown in Table 3 . The company that took part in the testing only measures distribution transport costs that amount to $€ 0.01394 / \mathrm{pcs}$, but based on data entered in the model, we were able to calculate all individual logistics cost components. The company's total logistics costs per product are $€ 0.01093$ ( $7.86 \%$ of the value of the product) and the test results showed a cost of $€ 0.01394 / \mathrm{pcs}$ (10.02\% of the value of the product). The share of each logistics cost component in the total logistics costs structure is as follows: packaging costs $17.5 \%$, distribution warehousing costs $1.15 \%$, delivery transport costs $78.4 \%$, capital cost in stocks $1.8 \%$ and purchasing warehousing costs $1.15 \%$. Final testing with the model resulted in a $27.53 \%$ increase in logistics costs, compared to the existing costs, which suggests a lack of coordination in the management of logistics costs within the company.
Despite the fact that distribution transport costs represent the largest portion of all logistics costs, a conclusion can be made that, unless all the other logistics cost components are calculated, effective management of logistics activities that could lead to individual improvements at the company level is not possible. For this purpose, a number of questions pertaining to logistics were formulated, which enable the users of the model to understand logistics costs management and simulate various decisionmaking scenarios:

1. Which packaging management approach would result in the lowest logistics costs?

The costs of non-returnable packaging are $€ 0.00243 /$ pcs. The use of returnable packaging would result reduce this cost to $€ 0.00155 / \mathrm{pcs}$, which would lead to savings on total logistics costs.

2. Which method of delivery would result in the lowest logistics costs?

The company does not combine delivery with other products. This method of delivery does not result in the lowest logistics costs. A simulation is required: combining products with other products with returnable packaging (Return Transport Price per Pieces - RTPP) and combined delivery with other products (Optimal Transport Price per Pieces - OTPP).

3. How does the number of shipments affect distribution transport costs and total logistics costs?

The company supplies its customers 12 times a year. The cost per unit is $€ 0.01093 /$ pcs. Reducing the number of shipments would increase the cost of capital in stocks, but on the other hand, it would significantly reduce distribution transport costs and total logistics costs (see Sub-Section 3.8). This would result in a lower level of logistics customer service, which would potentially affect customer satisfaction.

4. Which departments in the company have the greatest impact on the level of logistics costs?

The departments that have the greatest impact on the level of logistics costs are the ones that are directly involved in the distribution of the product. The impact of these departments on the level of logistics costs is $79.55 \%$.

5. Which warehousing approach would result in the lowest logistics costs?

Table 3. Comparison of the results of model testing

\begin{tabular}{|l|c|c|}
\hline \multicolumn{1}{|c|}{ Logistics cost component } & Company & Model results \\
\hline Packaging Cost (PC) per pieces & not measured & $€ 0.00243$ \\
\hline Distribution Warehousing Costs (DWC) per pieces & not measured & $€ 0.00016$ \\
\hline Delivery Transport Costs (DTC) per pieces & $€ 0.01093$ & $€ 0.01093$ \\
\hline Capital Costs in Stocks (CCS) per pieces & not measured & $€ 0.00022$ \\
\hline Purchasing Warehousing Costs (PWC) per pieces & not measured & $€ 0.00016$ \\
\hline Purchasing Transport Costs (PTC) per pieces & do not use & - \\
\hline Total Logistics Costs (TLC) per pieces & $€ 0.01093$ & $€ 0.01394$ \\
\hline Product Price (PP) & $€ 0.13907$ & $€ 0.13907$ \\
\hline Logistics Costs as a Proportion of the Price of the Product & $7.86 \%$ & $10.02 \%$ \\
\hline
\end{tabular}


The company uses its own warehouse facilities for purchasing and sales and does not require an external warehouse. Using the company's own warehouse facilities guarantees lower logistics costs. The company uses rented handling equipment in its warehouse. The model recommends a simulation of the impact that purchasing handling equipment would have on the company's overall logistics costs.

6. How does the number of days of safety stock per product affect the cost of capital in stocks and the total logistics costs?

Without safety stocks, the cost of capital in stocks would be reduced from $€ 0.00022$ to $€ 0.00011 / \mathrm{pcs}$. Total logistics costs would be reduced by a mere $0.8 \%$.

7. How does inventory turnover affect the total logistics costs?

Inventory turnover per each product take place twelve times a year or every 30 days. The cost per shipment is $€ 6.74$ or $€ 0.00022 / p c s$. Inventory turnover does not have a positive effect on logistics costs.

8. How does the payment period in purchasing affect the cost of capital in stocks and the total logistics costs? In purchasing, the payment period is 60 days and it has no significant impact on the cost of capital in stocks and on the total logistics costs.

9. How does the payment period in sales affect the cost of capital in stocks and the total logistics costs?

The payment period is 45 days and it has a positive effect on the cost of capital in stocks as it is shorter, compared to purchasing. If the payment deadline was 0 days, the cost of equity in stocks would be reduced from $€ 0.00022$ to $0.00010 / \mathrm{pcs}$, which means that the company would actually be financed by the suppliers.

10. What is the impact of the interest rate on total logistics costs?

The company is currently carrying a loan at a $1.3 \%$ interest rate. The impact of the interest rate on the total logistics costs of the product is minimal.

\subsection{Managerial and theoretical implications on logistics costs and processes}

The model is intended as a practical solution to the potential problems that companies may experience when managing logistics costs. The main advantage of the proposed model is that it enables functional departments to work together in the early stages of product development, through a clear definition of distribution costs, inventory costs, packaging costs, warehousing costs and other logistics support processes. This enables the user to have more control over the costs of logistics throughout the entire life cycle of the product and provides a systemic tool for individual logistics improvements. This process can involve employees from different business functions (sales, purchasing, logistics, production, etc.) and from different hierarchical levels (management, middle management, operational associates). This ensures vertical and horizontal integration of business functions via a single decision- making tool. It also improves the quality of information pertaining to the logistics costs for a particular product and to the logistics processes as support functions. The model enables even those employees who lack the necessary knowledge of logistics, but whose decisions nevertheless influence the level of logistics costs and the quality of customer service, to gain some insight into the process of logistics costs management. An important aspect of the practicality and usability of the model is that it allows the users to create simulations of various decision-making scenarios, through a series of logistics-related questions. This helps the users of the model to understand the specifics of logistics costs management and thereby improve the logistics processes in the company.

The results of testing the proposed model provide a theoretical justification for the need to manage the logistics costs for each particular product, as other models are focused exclusively on cost optimisation for individual logistics processes (for example, distribution, internal logistics and purchasing). The presented logistics cost approach therefore represents a novelty in the field that is the focus of this study. The model also represents an upgrade of the existing optimisation models by providing a better coverage of individual logistics processes, since it takes into account several different logistics cost components. This is especially important for a more unified management of logistics costs, as they are incurred in different business areas within the company.

\subsection{Limitations and further research directions}

A new method is proposed, which largely builds on the author's previous studies in the field of logistics costs management and requires additional testing in various industries. The first major limitation of the model stems from the nature of logistics costs management. Since these costs exist in different business areas, they can be difficult to identify. These include the costs of the information system and the administrative costs of the departments that deal with logistics. In addition, there are various fixed and variable costs associated with the use of equipment for the warehousing and transport of goods. It is therefore impossible to build a model capable of calculating all the costs of logistics that will arise during the life cycle of a product, at an early stage of the product's development.

The second limitation stems from the fact that input variables are often interdependent. An individual variable can be unrealistic, if it is based on historical data that may not remain the same in the future. This can result in inaccurate calculations of logistics costs and potentially in the wrong decisions being made. It is therefore advisable to periodically review individual key variables, in order to identify potential impacts on the total logistics costs of the product.

The testing was performed on one product only. It is therefore necessary to examine the possibilities of integrating the model into larger IT software solutions, for companies that produce several different products. 


\section{Conclusions}

The presented study represents one of the first contributions that deal with the management of logistics costs throughout a product's life cycle. The applicability of the model was tested in a multinational furniture company, highlighting the following main advantages of the model: focusing on the logistics costs for the product at an early stage in its development, taking into account several different logistics cost components and providing a better coverage of individual logistics processes. The model is characterised by a high degree of practicality and usability, since a comparison between the current situation and the model testing results identified important suggestions for improvements to logistics costs management in the analysed company.

The model complements existing knowledge and represents a practical tool for logistics professionals that allows more efficient logistics costs planning at an early stage in the development of the product, which can result in the long-term reduction in the total costs of logistics and improve the quality of business processes. Since what is proposed is a new method for managing logistics costs, it would be advisable to conduct additional testing on different products and in different industries in the future. Particular attention should be given to the possibility of integrating the model into larger business information solutions.

\section{References}

Ali, A. I.; O’Connor, D. J. 2013. Using truck-inventory-cost to obtain solutions to multi-period logistics models, International Journal of Production Economics 143(1): 144-150. https://doi.org/10.1016/j.ijpe.2012.12.022

Ballou, R. H. 2003. Business Logistics: Supply Chain Management. Prentice Hall. 816 p.

Becker, J.; Görke, M.; Felix, C.; Schmidt, M. 2016. Model-based potential analysis of the distribution logistics: a case study, Production Planning \& Control: the Management of Operations 27(9): 698-707.

https://doi.org/10.1080/09537287.2016.1166279

Berman, O.; Wang, Q. 2006. Inbound logistic planning: minimizing transportation and inventory cost, Transportation Science 40(3): 287-299. https://doi.org/10.1287/trsc.1050.0130

Bertazzi, L.; Speranza, M. G. 1999. Models and algorithms for the minimization of inventory and transportation costs: a survey, Lecture Notes in Economics and Mathematical Systems 480: 137-157. https://doi.org/10.1007/978-3-642-58568-5_7

Bertazzi, L.; Speranza, M. G.; Ukovich, W. 1997. Minimization of logistic costs with given frequencies, Transportation Research Part B: Methodological 31(4): 327-340. https://doi.org/10.1016/S0191-2615(96)00029-X

Blumenfeld, D. E.; Burns, L. D.; Daganzo, C. F.; Frick, M. C.; Hall, R. W. 1987. Reducing logistics costs at general motors, INFORMS Journal on Applied Analytics 17(1): 26-47. https://doi.org/10.1287/inte.17.1.26

Blumenfeld, D. E.; Burns, L. D.; Diltz, J. D.; Daganzo, C. F. 1985. Analyzing trade-offs between transportation, inventory and production costs on freight networks, Transportation Research Part B: Methodological 19(5): 361-380. https://doi.org/10.1016/0191-2615(85)90051-7
Burns, L. D.; Hall, R. W.; Blumenfeld, D. E.; Daganzo, C. F. 1985. Distribution Strategies that minimize transportation and inventory costs, Operations Research 33(3): 469-490. https://doi.org/10.1287/opre.33.3.469

Chow, G. 2007. A total logistics cost approach to measuring collateral benefits of security and supply chain improvements at international gateways, in Canada's Asia-Pacific Gateway and Corridor Initiative, 2-4 May 2007, Vancouver, British Columbia, Canada, 1-19.

Ghodsypour, S. H.; O'Brien, C. 2001. The total cost of logistics in supplier selection, under conditions of multiple sourcing, multiple criteria and capacity constraint, International Journal of Production Economics 73(1): 15-27.

https://doi.org/10.1016/S0925-5273(01)00093-7

Ji, M.; Fang, J.; Zhang, W.; Liao, L.; Cheng, T. C. E.; Tan, Y. 2018. Logistics scheduling to minimize the sum of total weighted inventory cost and transport cost, Computers \& Industrial Engineering 120: 206-215. https://doi.org/10.1016/j.cie.2018.04.041

Juntunen, J.; Juntunen, M.; Juga, J. 2015. Latent classes of service quality, logistics costs and loyalty, International Journal of Logistics Research and Applications: a Leading Journal of Supply Chain Management 18(5): 442-458.

https://doi.org/10.1080/13675567.2014.980793

Kiisler, A. 2008. Logistics in Estonian business companies, Transport 23(4): 356-362.

https://doi.org/10.3846/1648-4142.2008.23.356-362

Kivinen, P.; Lukka, A. 2004. Value Added Logistical Support Service: Logistics Cost Structure and Performance in the New Concept. Lappeenranta-Lahti University of Technology, Finland. 82 p.

Kim, G.; Wu, K.; Huang, E. 2015. Optimal inventory control in a multi-period newsvendor problem with non-stationary demand, Advanced Engineering Informatics 29(1): 139-145. https://doi.org/10.1016/j.aei.2014.12.002

Kutanoglu, E.; Lohiya, D. 2008. Integrated inventory and transportation mode selection: a service parts logistics system, Transportation Research Part E: Logistics and Transportation Review 44(5): 665-683.

https://doi.org/10.1016/j.tre.2007.02.001

Lau, H. C. W.; Nakandala, D. 2012. A pragmatic stochastic decision model for supporting goods trans-shipments in a supply chain environment, Decision Support Systems 54(1): 133-141. https://doi.org/10.1016/j.dss.2012.04.012

Madadi, A.; Kurz, M. E.; Ashayeri, J. 2010. Multi-level inventory management decisions with transportation cost consideration, Transportation Research Part E: Logistics and Transportation Review 46(5): 719-734.

https://doi.org/10.1016/j.tre.2009.12.012

McCarthy-Byrne, T. M.; Mentzer, J. T. 2011. Integrating supply chain infrastructure and process to create joint value, International Journal of Physical Distribution \& Logistics Management 41(2): 135-161. https://doi.org/10.1108/09600031111118530

Miranda, P. A.; Garrido, R. A. 2009. Inventory service-level optimization within distribution network design problem, International Journal of Production Economics 122(1): 276-285. https://doi.org/10.1016/j.ijpe.2009.06.010

Perera, S.; Janakiraman, G.; Niu, S.-C. 2018. Optimality of (s, S) inventory policies under renewal demand and general cost structures, Production and Operations Management 27(2): 368-383. https://doi.org/10.1111/poms.12795

Petraška, A.; Čižiūnienė, K.; Jarašūnienè, A.; Maruschak, P.; Prentkovskis, O. 2017. Algorithm for the assessment of heavyweight and oversize cargo transportation routes, Journal of Business Economics and Management 18(6): 1098-1114. https://doi.org/10.3846/16111699.2017.1334229 
Petraška, A.; Čižiūnienė, K.; Prentkovskis, O.; Jarašūnienè, A. 2018. Methodology of selection of heavy and oversized freight transportation system, Transport and Telecommunication 19(1): 45-58. https://doi.org/10.2478/ttj-2018-0005

Rybakov, D. S. 2018. A process model of a logistics system as a basis for optimisation programme implementation, International Journal of Logistics Research and Applications: a Leading Journal of Supply Chain Management 21(1): 72-93. https://doi.org/10.1080/13675567.2017.1361910

Rybakov, D. S. 2017. Total cost optimisation model for logistics systems of trading companies, International Journal of Logistics Systems and Management 27(3): 318-342. https://doi.org/10.1504/IJLSM.2017.084469

Sajadieh, M. S.; Thorstenson, A.; Jokar, M. R. A. 2010. An integrated vendor-buyer model with stock-dependent demand, Transportation Research Part E: Logistics and Transportation Review 46(6): 963-974. https://doi.org/10.1016/j.tre.2010.01.007

Santa, R.; Bretherton, P.; Ferrer, M.; Soosay, C.; Hyland, P. 2011. The role of cross-functional teams on the alignment between technology innovation effectiveness and operational effectiveness, International Journal of Technology Management 55(1/2): 122-137. https://doi.org/10.1504/IJTM.2011.041683

Shang, K.-C. 2004. The effects of logistics measurement capability on performance, Asia Pacific Management Review 9(4): 671-687. https://doi.org/10.6126/APMR.2004.9.4.06

Speranza, M. G.; Ukovich, W. 1994. Minimizing transportation and inventory costs for several products on a single link, $O p$ erations Research 42(5): 879-894.

https://doi.org/10.1287/opre.42.5.879

Stock, J. R.; Lambert, D. M. 2000. Strategic Logistics Management. McGraw-Hill/Irwin. 896 p.

Strack, G.; Pochet, Y. 2010. An integrated model for warehouse and inventory planning, European Journal of Operational Research 204(1): 35-50. https://doi.org/10.1016/j.ejor.2009.09.006

Škerlič, S.; Muha, R. 2016. The importance of systems for controlling logistics costs in the supply chain: a case study from the Slovenian automotive industry, Promet - Traffic \& Transportation 28(3): 299-310. https://doi.org/10.7307/ptt.v28i3.1881

Škerlič, S.; Muha, R.; Logožar, K. 2016. A decision-making model for controlling logistics costs, Tehnički Vjesnik - Tehnical Gazette 23(1): 145-156. https://doi.org/10.17559/TV-20141015121023

Tancrez, J.-S.; Lange, J.-C.; Semal, P. 2012. A location-inventory model for large three-level supply chains, Transportation Research Part E: Logistics and Transportation Review 48(2): 485-502. https://doi.org/10.1016/j.tre.2011.10.005

Waller, M. A.; Fawcett, S. E. 2012. The total cost concept of logistics: one of many fundamental logistics concepts begging for answers, Journal of Business Logistics 33(1): 1-3. https://doi.org/10.1111/j.0000-0000.2011.01033.x

Wang, X.; Cheng, T. C. E. 2009. Logistics scheduling to minimize inventory and transport costs, International Journal of Production Economics 121(1): 266-273. https://doi.org/10.1016/j.ijpe.2009.05.007

Zanjirani Farahani, R.; Asgari, N.; Davarzani, H. 2009. Supply Chain and Logistics in National, International and Governmental Environment: Concepts and Models. Physica-Verlag Heidelberg. 316 p. https://doi.org/10.1007/978-3-7908-2156-7

Zhao, Q.-H.; Wang, S.-Y.; Lai, K.-K.; Xia, G.-P. 2004. Model and algorithm of an inventory problem with the consideration of transportation cost, Computers \& Industrial Engineering 46(2): 389-397. https://doi.org/10.1016/j.cie.2003.12.019 